the $\mathrm{pH}$ was between 4.0 and 7.0 , while hydrolysis of I with $\mathrm{Cu}^{2+}(\mathrm{pH} 4.5-7.0)$ proceeded too rapidly to measure the rate constant. Since acyl hydrazines are known to form the stable 5 -membered chelate ring compounds, ${ }^{7)}$ acyl guanidines are expected to form a similar metal complex. It appears probable that the catalytic effect of $\mathrm{Cu}^{2+}$ is due to the formation of the metal complex. The presumed reaction mechanism is described in Chart 1 . It is analogous to the acid catalyzed hydrolysis of carboxamides. The mechanism involves the formation of the carbonium cation in a 6-membered chelate ring (V), followed by the hydration into (VI), and subsequently the rearrangement of hydrogen to form the tetrahedral intermediate (VII).

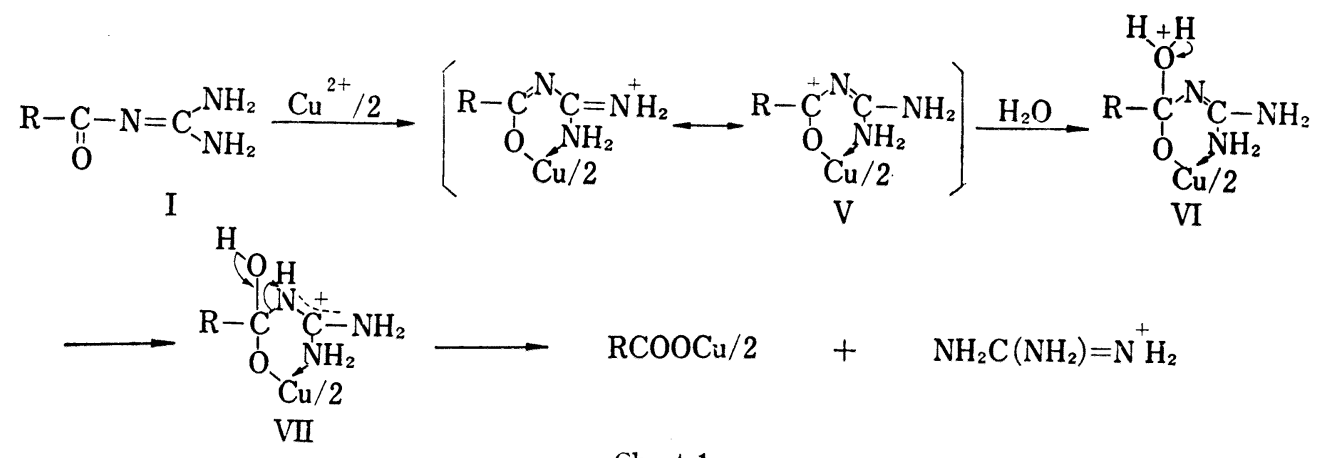

Chart 1

In order to clarify the correlation between metal ions and the hydrolysis of Ia or II in the tissue cell systems, further works are now in progress.

Department of Chemistry,

Japan Women's University

Tadakazu TsujI

Mejiro-dai, Bunkyo-ku, Tokyo

Received November 25, 1971

7) W.O. Foye, J. Pharm. Sci., 50, 93 (1961).

\title{
On the Structure of Kidjolanin and the Position of the Esterlinkage of Penupogenin
}

The isolation of sarcostin (I), utendin (II), and tomentogenin from the stems of Marsdenia tomentosa Decne (Asclepiadaceae, Japanese name: Kijoran) has been reported previously and the structure (III) was given for tomentogenin.1) In this communication, we wish to describe the isolation and the structure of a new aglycone, kidjolanin, from the same stems and the position of the ester linkage of penupogenin ${ }^{2)}$ (IV).

1) H. Mitsuhashi, I. Takemori, Y. Shimizu, T. Nomura, and E. Yamada, Chem. Pharm. Bull. (Tokyo), 10, 804 (1962); H. Mitsuhashi, T. Sato, T. Nomura, and I. Takemori, ibid., 13, 267 (1965); M. Fukuoka and $H$. Mitsuhashi, ibid., 16, 1634 (1968).

2) H. Mitsuhashi and Y. Shimizu, Chem. Pharm. Bull. (Tokyo), 10, 725 (1962). 
The aglycone mixture, obtained after the mild acid hydrolysis of the crude glycoside, ${ }^{1)}$ was worked up by repeated silica gel column chromatography and preparative thin-layer chromatography (preparative TLC). This procedure yielded two compounds. One is identified with penupogenin and the other is a new aglycone, named kidjolanin, $\mathrm{mp} 147-149^{\circ}$ from ether.

Kidjolanin (V) shows the following data: green colour with Liebermann-Burchard reaction, violet-greenish blue with $\mathrm{SbCl}_{3}$, negative Keller-Kiliani reaction, $[\alpha]_{\mathrm{D}}^{15}+63.2^{\circ}(c=1.0$ in $\mathrm{CHCl}_{3}$ ), Anal. Calcd. for $\mathrm{C}_{30} \mathrm{H}_{38} \mathrm{O}_{7}:$ C, $70.57 ; \mathrm{H}, 7.50$. Found: C, 70.40; H, 7.61, ultraviolet absorption $\lambda_{\max }^{\text {Erof }} \mathrm{m} \mu(\log \varepsilon): 273(4.30)$, infrared (IR) absorption $\nu_{\max }^{\text {Nujol }} \mathrm{cm}^{-1}: 3300,1705,1680$, $1640,1580,1280$, nuclear magnetic resonance (NMR) $\left(\mathrm{CDCl}_{3}\right) \tau: 8.85\left(19-\mathrm{CH}_{3}\right), 8.52\left(18-\mathrm{CH}_{3}\right)$, $7.78\left(3 \mathrm{H}, \mathrm{s}, 21-\mathrm{CH}_{3}\right), 6.44(1 \mathrm{H}$, broad $\mathrm{m}, 3 \alpha$-proton $), 5.32(1 \mathrm{H}, \mathrm{t}, J=8 \mathrm{~Hz}, 12 \alpha$-proton $), 4.64$ $(1 \mathrm{H}$, broad t, 6 -vinyl proton), $3.71(1 \mathrm{H}, \mathrm{d}, J=16 \mathrm{~Hz}), 2.70-2.40(5 \mathrm{H}, \mathrm{m}$, aromatic protons), $2.40(1 \mathrm{H}, \mathrm{d}, J=16 \mathrm{~Hz})$, Mass Spectrum $m / e: 510\left(\mathrm{M}^{+}\right), 467\left(\mathrm{M}^{+}-43\right),{ }^{3)} 319\left(\mathrm{M}^{+}-43\right.$ - cinnamic acid), $301\left(319-\mathrm{H}_{2} \mathrm{O}\right), 283\left(319-2 \mathrm{H}_{2} \mathrm{O}\right), 265\left(319-3 \mathrm{H}_{2} \mathrm{O}\right), 131$ (base peak), 103 . From these data it is suggested that kidjolanin is a cinnamoyl ester of polyoxygenated pregnane derivative. Especially, from the chemical shifts and the coupling constants of the NMR spectrum, the cinnamoyl group is present at $\mathrm{C}-12$ of which the orientation is $\beta$.

$V$ was hydrolyzed with $5_{\%}^{\circ}$ methanolic potassium hydroxide to cinnamic acid, mp $133^{\circ}$, as an acidic product and deacylmetaplexigenin (VI), ${ }^{4)} \mathrm{mp} 218-223^{\circ}$, as a neutral product which was identical with an authentic sample by a mixed melting point and comparisons of TLC and of IR spectra.

Acetylation of $\mathrm{V}$ with acetic anhydride-pyridine afforded a monoacetate (VII), $\mathrm{mp}$ 198$210^{\circ}$, IR $\nu_{\max }^{\text {Nuji }} \mathrm{cm}^{-1}: 3400,1710,1705,1640,1580,1280,1180$. A new methyl signal is appeared at $\tau 7.97$ and $3 \alpha$-proton signal is shifted to 5.36 in the NMR spectrum of this compound.

Reduction of $\mathrm{V}$ with $\mathrm{NaBH}_{4}$ in methanol ${ }^{5}$ ) afforded IV, which was identical with an authentic sample by a mixed melting point and comparisons of TLC and of IR spectra. From. this point it is concluded that penupogenin is 12-O-cinnamoyl sarcostin. The presence of the ion $m / e 467\left(\mathrm{M}^{+}-45\right)^{3)}$ in the mass spectrum of IV also supports this conclusion.

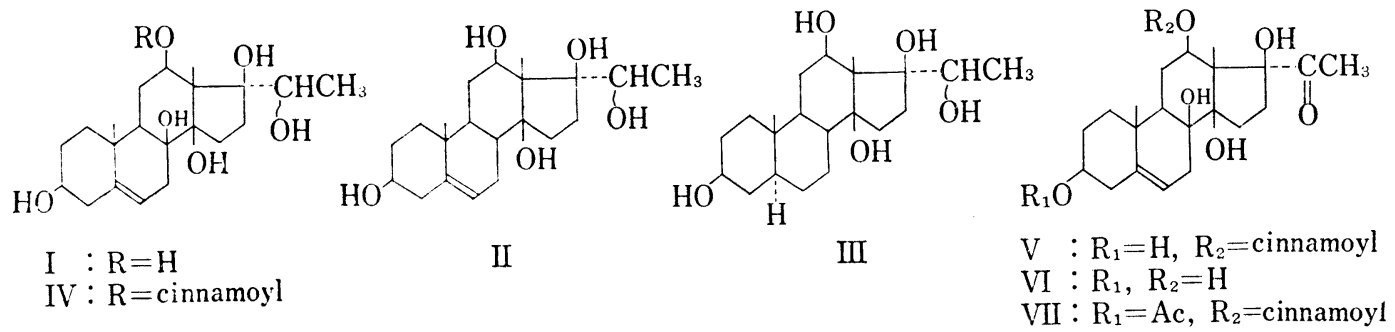

Acknowledgement We thank to Mr. Y. Kasuya (Chiba Experimental Plantation of Tokyo University) for collecting the plants, to Miss S. Fukuoka for NMR spectral measurement, to Miss A. Maeda for elemental analysis, and to Miss M. Takahashi for mass spectral measurement.

Faculty of Pharmaceutical Sciences, Hokkaido University

Sapporo
TAMIHIKo SASAKI

KOJI HAYASHI

Hiroshi Mitsuhashi

Received December 3, 1971

3) M. Fukuoka, K. Hayashi, and H. Mitsuhashi, Chem. Pharm. Bull. (Tokyo), 19, 1469 (1971).

4) H. Mitsuhashi and T. Nomura, Chem. Pharm. Bull. (Tokyo), 11, 1198 (1963).

5) H. Heymann and L.F. Fieser, J. Am. Chem. Soc., 73, 5252 (1951). 